\title{
INVESTIGATION OF BIOACTIVE CONSTITUENTS AND BIOLOGICAL ACTIVITIES OF DIFFERENT FRACTIONS FROM HERNIARIA HEMISTEMON J.GAY
}

\author{
Gameel A M Elhagali ${ }^{1, *}$, Atef E. M. Abozeed ${ }^{2}$, Kobisi A. Abd elnaser ${ }^{3}$, Youssif M.Youssif ${ }^{2}$. \\ ${ }^{1}$ Chemistry Department, Faculty of Science, Al-Azhar University, Cairo, Egypt. \\ ${ }^{2}$ Medicinal and aromatic plants department, Desert Research Center, 11753 Matariya, Cairo, Egypt. \\ ${ }^{3}$ Plant protection department, Desert Research Center, 11753 Matariya, Cairo, Egypt.
}

*Corresponding author: elhag1970@yahoo.com

\begin{abstract}
This study was carried out the phytochemical screening and evaluate antibacterial, antifungal and antioxidants effects of petroleum ether $\left(40-60{ }^{\circ} \mathrm{C}\right)$, diethyl ether, chloroform, ethyl acetate, ethanol $96 \%$ and ethanol $70 \%$ fractions obtained from the aerial part of Herniaria hemostimon J. Gay. Phytochemical analysis showed the presence of terpenoids, steroids, flavonoids, alkaloids, tannins and saponins in different fractions the plant. Quantitative concentration of phenols, flavonoids, alkaloids, tannins and saponins were detected. HPLC analysis of $\mathrm{H}$. hemostimon identified 21 flavonoids and 21 phenolic compounds. Successive fractionation has been carried out where Di-(2-ethylhexyl) phthalate (DEHP and protocatechuic acid were isolated and identified using FT-IR, ${ }^{1} \mathrm{H}-\mathrm{NMR}$ and MS spectroscopic. Furthermore, the antimicrobial activity of successive extract of $\mathrm{H}$. hemistemon against 5 bacterial strains and 2 fungal and yeast strains carried out by the disc diffusion method. The diethyl ether and ethyl acetate fraction showed the highest activity against all the tested bacterial and fungal strains. The ethyl acetate fraction showed the highest antioxidant activity. This study suggested that the bioactivities of $\mathrm{H}$. hemistemona can be used as a source of medicinal compounds due to there's significant antioxidant and antimicrobial activities.
\end{abstract}

Keywords: Herniaria hemistemon; antimicrobial; antioxidants; HPLC.

\section{INTRODUCTION}

Medicinal and aromatic plants are considered the most important natural products which represent the main source of novel drugs used in treatment of many diseases that infect human [1]. These plants contain highly bioactive components. They also have great importance in folk medicine in treatment of diseases such as, diabetes, ulcers, cancer, skin inflammation, intestinal disorders and hypertension. The drugs isolated from natural sources are safer and with fewer side effects than chemically synthesized [2]. H. hemistemon is a genus of Herniaria belonging to family Caryophyllacae (pink family), which is one of the largest families in the plant kingdom known to be rich in medicinal plants. It consists of about 89 genera and 2070 species [3]. Herniaria genus represented in Egypt by five species [4]. The genus name derived from the Latin word hernia because it was believe that the herb could cure hernia. H. hemistemon had significant antioxidant activity [5]. $H$. hemistemon is grazing and medicinal plant [6], where the whole plant used in Europe as a treatment for hernias [7]. Phytochemical analysis of $H$. hemistemon revealed that five flavonoids compounds were isolated and identified as vitexin, kaempferol, quercetin-3$O$-glucoside-7- $O$-rhamnoside, kaempferol-7- $O$ rhamnoglucoside, and kaempferol 4'-methyl ether and showed high antioxidant activity against (DPPH). GLC analysis of the fatty acid revealed the presence of the 14 fatty acids in which palmitic acid $(21.62 \%)$ represented the major constituent, the fatty acids are exhibit antibacterial and antifungal properties [5]. In the present study, the phytochemical screening, antibacterial, antifungal and antioxidant activities of different fractions were evaluated. Secondary metabolites were identified in order to understand the compounds involved in each individual fraction bioactivity.

\section{MATERIAL AND METHODS}

\subsection{Plant Material}

Collection of Herniaria hemistemon J.Gay aerial parts occurred during May 2015 in the 
flowering stage from Siwa region Matrouh governorate, northwest coast, Egypt. Dr Atia Eisa, lecturer of plant taxonomy, Faculty of Science, Damanhur University recognized the plant species a voucher specimen is deposited in the herbarium, Desert Research Center (DRC), Cairo, Egypt. Synonyms: Herniaria fruticosa Delile and Herniaria sphacelata hochst.

\subsection{Equipment, Materials and Chemicals}

Organic solvents of different polarities were purchased from El-Naser pharmaceutical chemicals Co. (ADWIC) Egypt, Sigma and Merck Co. The Successive extraction of Herniaria hemistemon was performed using a Soxhlet apparatus, HPLC, Agilent 1100 series quaternary pump (Waldborn, Germany), connected to a photodiode array detector with variable wavelengths $\lambda$ max 340 and $280 \mathrm{~nm}$, (Agilent Technologies, USA). Column used is Zorbax $300 \mathrm{SB}$ C18 (150 mm, $4.6 \mathrm{~mm}, 5 \mu \mathrm{m})$. ${ }^{1}$ HNMR (Bruker $400 \mathrm{MHz}$ ) Micro analytical Unit, Faculty of Pharmacy Cairo University. Mass spectrum (Thermo Scientific; GC/MS model ISQ LT) using Thermo X-Calibur software at the Regional Center for Mycology and Biotechnology (RCMB), Al-Azhar University, Nasr City, Cairo. PerkinElmer Spectrum 100 FT-IR using $\mathrm{KBr}$ method Spectrophotometer. 1, 1-diphenyl-2picrylhydrazyl radical ((DPPH) SigmaAldrich).

\subsection{Preparation of the Plant Extracts}

Polarity is a very important factor when considering the choice of solvent for extraction and fractionation processes in testing the extracts of different organic solvents for detecting the plant constituents. $100 \mathrm{gm}$ of the air dried powder of $H$. hemistemon were subjected to successive extraction using different organic solvents using soxhlet apparatus, Petroleum ether $\left(40-60^{\circ} \mathrm{C}\right)$, diethyl ether, chloroform, ethyl acetate, ethanol 96\% and ethanol $70 \%$, solvents were used in the order of increasing polarity and each extract was concentrated using rotary vacuum evaporator (Buchi, G. Switzerland) at $40-50^{\circ} \mathrm{C}$.

\subsection{Phytochemical Screening}

\subsubsection{Preliminary Phytochemical Screening}

Testing for tannins, saponins, Glycosides and /or carbohydrates according to Balbaa [8], testing for sterols and terpenes according to Brieskorn et al [9], testing of alkaloids according to Woo et al [10] and testing for flavonoids and phenolic compounds according to Edeoga et al [11].

\subsubsection{Investigation of total active Constituents:}

The total active constituents content were determined in May 2015, this may be due to high water resources (rainfall) leading to high metabolic rates in accordance to our results. Total flavonoids were determined spectrophotometrically and calculated as rutin according to Samatha et al [12]. Total phenolic according to Makkar et al [13], Total tannins according to Ali et al [14]. Finally saponin and alkaloid content were determined according to Honerlagen and Tretter [15].

\subsubsection{Identification of Phenolic and flavonoid compounds using HPLC.}

Quantitative and qualitative estimation for the phenolic and flavonoid compounds of $H$. hemostimon methanol extract were achieved by HPLC, where each compound was separated and identification was done using authentic pattern [16].

\section{ANTIMICROBIAL ASSAY:}

\subsection{Microbial strains:}

The effect of successive extracts using organic solvents of petroleum ether $\left(40-60{ }^{\circ} \mathrm{C}\right)$, diethyl ether, chloroform, ethyl acetate ethanol $96 \%$ and ethanol $70 \%$ fractions on some pollutant micro-organisms were achieved. The bacterial strains were obtained from Plant Protection Department, Desert Research Center (DRC), Cairo, Egypt. While fungal and yeast strains were obtained from nosocomial infections. The bacterial, fungal and yeast strains checked for purity, identity and regenerated to obtain active microorganisms. Gram positive species (Staphylococcus aureus, Bacillus subtilis and Enterococcus faecalis), gram negative species (Escherichia coli and Pseudomonas aeruginosa) and fungal species Aspergillus niger and Candida albicans were tested. The successive extract was dissolved in Dimethylformamide (DMF) for antimicrobial investigation at the final concentration of $(10$ 
$\mathrm{mg} / \mathrm{ml}$ ). The antimicrobial activities of successive fractions were carried out by the disc diffusion method. For preparation of microbial inocula, the bacterial density was adjusted with sterile saline to approximately 108 colony forming units (CFU) per ml (optical density was adjusted at 0.5 McFarland turbidity) and the fungal spores were washed from the surface of agar plates with sterile $0.85 \%$ saline containing $0.1 \%$ Tween $80(\mathrm{v} / \mathrm{v})$. The spores suspension were adjusted with sterile saline to a concentration of approximately $1.0 \times 105$ in a final volume of 100 $\mu \mathrm{l}$ per $\mathrm{ml}$ [26].Yeast inoculum suspension was adjusted with sterile saline to approximately $1 \times 106$ to $5 \times 106$ yeast cell per ml (optical density was adjusted at $0.5 \mathrm{McFarland}$ turbidity [17].

\subsection{Minimum inhibitory concentrations (MIC's) determination of the effective plants extract}

To determination of MIC of The most effective plant extracts which exhibiting a strong antibacterial and antifungal by using disk diffusion method and evaluate their efficiency against test bacterial and fungal strains. Different concentrations of the effective plant extract $(10,20,30,40,50,60,70,80,90$ and $100 \mathrm{ug} / \mathrm{ml}$ ) were prepared separately and dissolved in DMSO, and requisite amount over sterilized filter paper discs (8 $\mathrm{mm}$ in diameter). Sterilized Petri dishes containing MuellerHilton agar and potato dextrose agar media were seeded with bacterial and fungal strains. The loaded filter paper discs with different concentrations of the effective plant extract were placed on the top of media plates and kept in the fridge at $5^{\circ} \mathrm{C}$ for $2 \mathrm{~h}$. then incubated at suitable temperature for $24 \mathrm{~h}$. The inhibition zones of effective plant extract were recorded.

\section{Determination of antioxidant activity}

Free radical scavenging assay using 1, 1diphenyl-2- picrylhydrazyl radical (DPPH) Sigma-Aldrich) was carried out according to Yildirim et al [24], concentrations of the tested extract and ascorbic acid as a reference antioxidant control $(125,250,500$ and 1000 $\mu \mathrm{g} / \mathrm{ml})$, (\%) Scavenging DPPH calculated as following:

(\%) Scavenged DPPH = Absorbance of control - Absorbance of extract

Absorbance of control

\section{RESULTS AND DISCUSSION:}

\subsection{Phytochemical Screening:}

The results of phytochemical screening of the successive extracts of $H$. hemistemon plant showed that, it contains flavonoids, coumarins, alkaloids, tannins, sterols and/or terpenes, glycosides and/or carbohydrates and saponins, the resins not detected as represented in table (1).

\subsection{Investigation of total active constituents}

Quantitative analysis of phenols, flavonoids, tannins, alkaloids and saponins were recorded in table (2) which showed as $312 \pm 0.8 \mathrm{mg} / \mathrm{g}$ (as gallic acid equivalent), $238 \pm 0.6 \mathrm{mg} / \mathrm{g}$ (as rutin equivalent), $3.67 \pm 0.2$ $\mathrm{mg} / \mathrm{g}, \quad 0.83 \pm 0.2 \mathrm{mg} / \mathrm{g}$ and $3.24 \pm 0.6 \mathrm{mg} / \mathrm{g}$ respectively.

Table (2): Total active materials of the aerial parts of Herniaria hemistemon.

\begin{tabular}{|c|c|}
\hline Secondary Metabolites & $\begin{array}{c}\text { Dry } \\
\text { Weigh(mg/g) }\end{array}$ \\
\hline
\end{tabular}

Table (1). Phytochemical analysis of successive extracts of Herniaria hemistemon Aerial Parts.

\begin{tabular}{|c|c|c|c|c|c|c|}
\hline Test & $\begin{array}{c}\text { Petroleum } \\
\text { Ether } \\
\left(\mathbf{4 0 - 6 0}{ }^{\circ} \mathbf{C}\right)\end{array}$ & $\begin{array}{c}\text { diethyl } \\
\text { ether }\end{array}$ & Chloroform & $\begin{array}{c}\text { Ethyl } \\
\text { acetate }\end{array}$ & Ethanol 96\% & Ethanol 70\% \\
\hline Flavonoids & - & - & + & + & + & + \\
\hline Coumarins & - & - & + & - & - & - \\
\hline Alkaloids & - & - & + & - & - & - \\
\hline Tannins & - & - & - & + & + & + \\
\hline $\begin{array}{c}\text { Glycosides and / } \\
\text { or carbohydrates }\end{array}$ & - & - & - & - & + & + \\
\hline Sterols and / or terpenens & + & + & + & - & - & - \\
\hline Saponins & - & - & - & + & + & + \\
\hline Resins & - & - & - & - & - & - \\
\hline
\end{tabular}

(+) mean present, (-) mean absent. 


\begin{tabular}{|c|c|}
\hline Total phenolic (Gallic acid) & $312 \pm 0.8$ \\
\hline Total flavonoids (rutin) & $238 \pm 0.6$ \\
\hline Total tannins & $3.67 \pm 0.2$ \\
\hline Total alkaloids & $0.83 \pm 0.2$ \\
\hline Total Saponins & $3.24 \pm 0.6$ \\
\hline
\end{tabular}

\subsection{Determination of percentage yield of successive extraction}

Percentage yield obtained from each solvent using a Soxhlet apparatus[18] was concentrated, dried and weighed (2.02\%, $1.88 \%, 0.76 \%, 9.01 \%, 12.99 \%$ and $14.43 \%$ ) of petroleum ether $\left(40-60^{\circ} \mathrm{C}\right)$, diethyl ether, chloroform, ethyl acetate, ethanol $96 \%$ and ethanol $70 \%$, respectively. The obtained percentage of total residues was (41.09\%). Successive fractionation showed that ethanol $70 \%$ fraction has the highest percentage
Table (3). Determination of percentage yield of successive extraction of Herniaria hemistemon using soxhlet apparatus

\begin{tabular}{|l|c|}
\hline Solvent extract & Percentage (\%) \\
\hline Petroleum ether $\left(40-60^{\circ} \mathrm{C}\right)$ & 2.02 \\
\hline Diethyl ether & 1.88 \\
\hline Chloroform & 0.76 \\
\hline Ethyl acetate & 9.01 \\
\hline Ethanol 96\% & 12.99 \\
\hline Ethanol 70\% & 14.43 \\
\hline Total \% & 41.09 \\
\hline
\end{tabular}

\subsection{Identification of Phenolic and flavonoid compounds using HPLC.}

Quantitative and qualitative estimation for the phenolic and flavonoid compounds of the methanol extract of $H$. hemostimon were

Table (4). HPLC analysis for Phenolic compounds of Herniaria hemistemon

\begin{tabular}{|c|l|c|c|}
\hline No. & Phenolic Compound & RT & Result (ppm) \\
\hline 1 & Pyrogallol & 6.99 & 103.89 \\
\hline 2 & Gallic & 7.07 & 5.35 \\
\hline 3 & 4-Amino-benzoic & 8.39 & 1.52 \\
\hline 4 & Protocatechuic & 8.44 & 9.27 \\
\hline 5 & Catechin & 8.62 & 11.43 \\
\hline 6 & Catechol & 9.04 & 25.51 \\
\hline 7 & Epicatechin & 8.62 & 4.73 \\
\hline 8 & 4 hydroxybenzoic acid & 9.66 & 30.11 \\
\hline 9 & Chlorogenic & 10.06 & 8.50 \\
\hline 10 & Vanillic & 10.16 & 16.56 \\
\hline 11 & Caffeic & 10.29 & 3.97 \\
\hline 12 & P-coumaric & 11.58 & 4.83 \\
\hline 13 & Ferulic & 11.9 & 11.90 \\
\hline 14 & Iso- ferrulic & 12.12 & 3.00 \\
\hline 15 & E-vanillic & 12.24 & 35.17 \\
\hline 16 & Benzoic & 13.3 & 26.64 \\
\hline 17 & Ellagic & 13.43 & 252.92 \\
\hline 18 & $3,4,5-$ methoxycinnamic & 14.12 & 13.56 \\
\hline 19 & Coumarin & 14.47 & 3.48 \\
\hline 20 & Cinnamic & 15.26 & 0.30 \\
\hline 21 & Salicylic & 16.31 & 3.30 \\
\hline
\end{tabular}

amounted to $14.43 \%$ while the lowest one was that of chloroform extract as shown in table (3). achieved by using HPLC, where each compound was separated and identified using 
authentic pattern. It found that twenty one phenolic compounds according to their retention time, the maximum value reviled methanolic extract of $H$. hemostimon Ellagic acid $252.92 \mathrm{ppm}$ as table (4) and fig. (1) While twenty one flavonoid compounds were identified and the maximum value reveled methanolic extract of $H$. hemostimon luteolin- 6-arabinose-8- glucoside $174.06 \mathrm{ppm}$ as table (5) and fig. (2).

\subsection{Extraction and isolation}

Ethyl acetate fraction ( $7.4 \mathrm{~g}$ ) was applied on the top of silica gel column chromatography. Elution started with diethyl ether gradual increasing of ethyl acetate $(5 \%, 10 \%, 15 \%$,

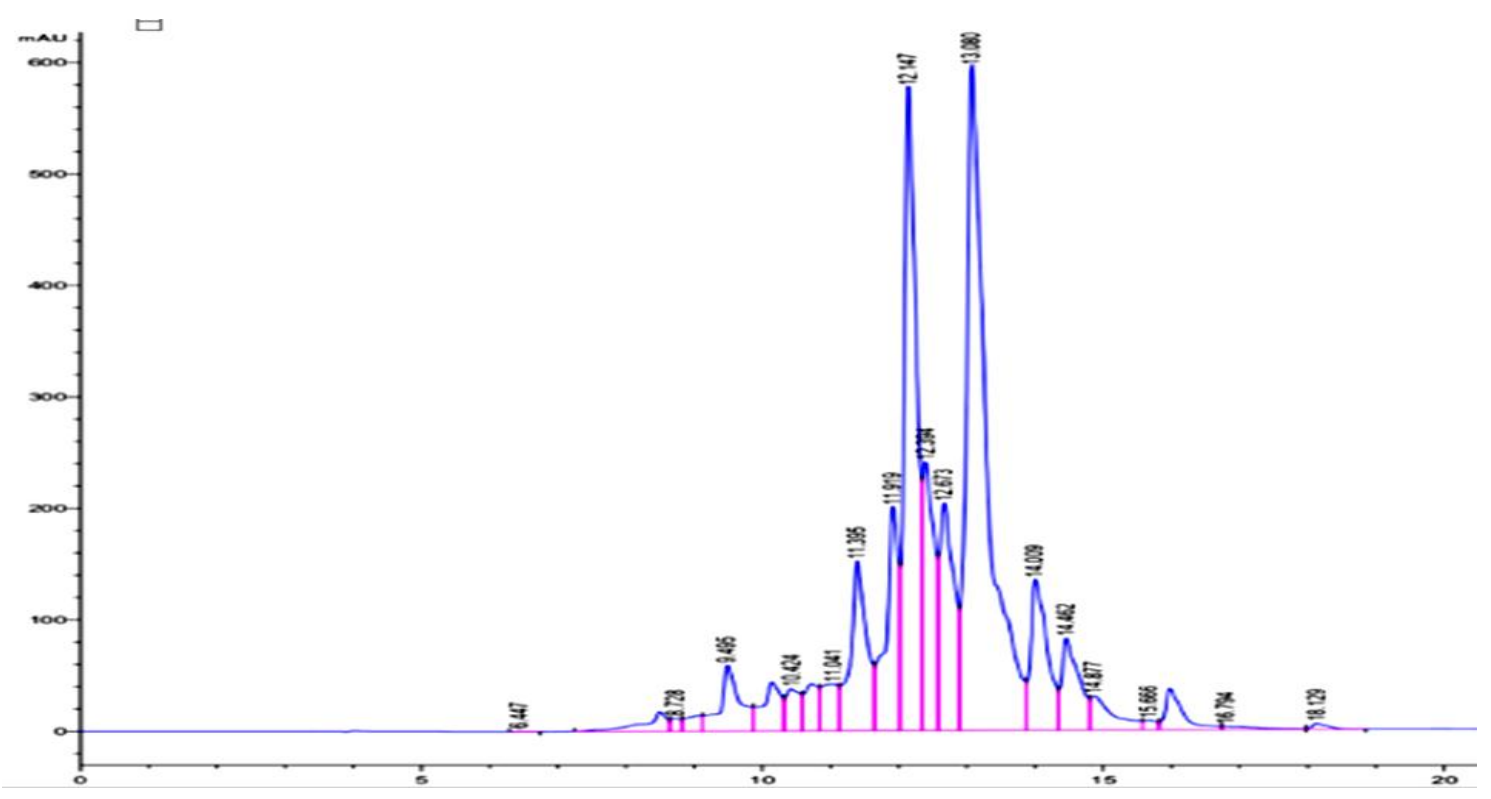

Fig. (1). HPLC of phenolic compounds for Herniaria hemistemon.

Table (5). HPLC of flavonoid compound for Herniaria hemistemon

\begin{tabular}{|c|l|c|c|}
\hline No. & Flavonoid Compound & RT & Results $\mathbf{( p p m )}$ \\
\hline 1 & luteolin-6-arabinose-8- glucoside & 9.55 & 174.06 \\
\hline 2 & luteolin-6-glucosyl-8-arabinoside & 10.75 & 3.03 \\
\hline 3 & apigenin-6-arabinose-8- glactose & 11.69 & 6.64 \\
\hline 4 & Apigenin-6-rhamnosyl-8-glucoside & 12.08 & 9.87 \\
\hline 5 & Apigenin-6-glucosyl-8- Rhamnoside & 12.14 & 3.96 \\
\hline 6 & Naringin & 12.33 & 8.40 \\
\hline 7 & Hesperidin & 12.44 & 39.64 \\
\hline 8 & Quercetin-3-O-glucoside & 12.54 & 4.06 \\
\hline 9 & Rutin & 12.60 & 6.36 \\
\hline 10 & Apigenin-7-O-neohesperidoside & 13.05 & 3.96 \\
\hline 11 & Kaempferol 3,7-dirhamnoside & 13.24 & 4.04 \\
\hline 12 & Quercetrin & 13.44 & 16.07 \\
\hline 13 & Quercetin & 14.99 & 1.22 \\
\hline 14 & Naringenin & 15.07 & 1.07 \\
\hline 15 & Kaempferol-3-glucoside-2"-pcoumaroyl & 15.16 & 5.92 \\
\hline 16 & Hesperetin & 15.36 & 1.08 \\
\hline 17 & Kaempferol & 16.38 & 0.92 \\
\hline 18 & Rhamnetin & 16.44 & 0.45 \\
\hline 19 & Apigenin & 16.58 & 1.3 \\
\hline 20 & Apigenin -7-O-glucoside & 17.25 & 0.43 \\
\hline 21 & Acacetin & 18.84 & 7.75 \\
\hline
\end{tabular}




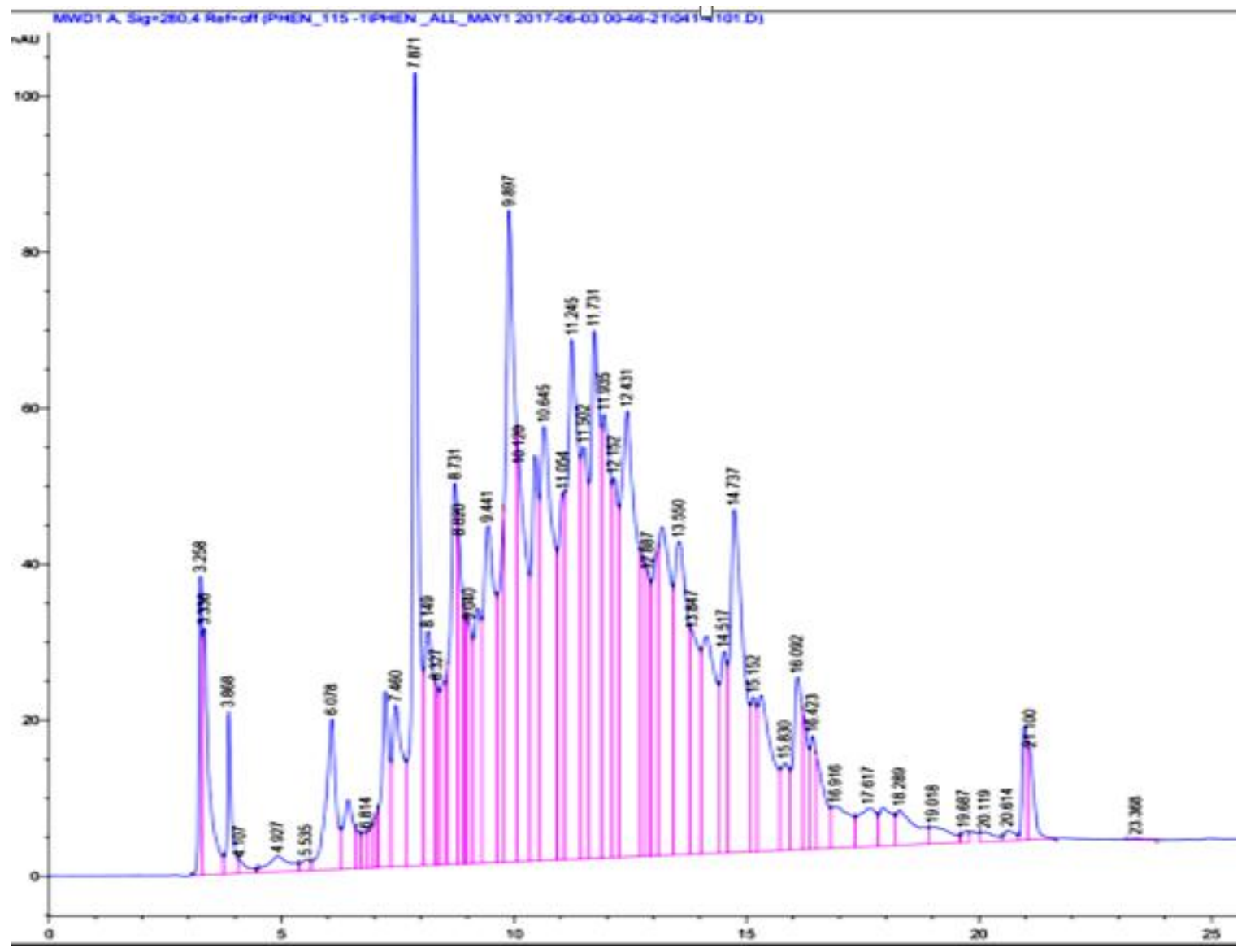

Fig. (2). HPLC of flavonoid compound for Herniaria hemistemon

$20 \%$, till pure ethyl acetate finally. About 134 fractions were collected, evaporated and concentrated under reduced pressure, collective fractions were obtained according to paper chromatography manner using system ( $n$ Butanol: acetic acid: water (BAW) 4: 1: 5 $\mathrm{v} / \mathrm{v} / \mathrm{v})$ upper phase and TLC using different solvent systems (ethyl acetate: methanol: water 30: 5: 4) and (chloroform: methanol 95: 5), examined under UV light. One collective fraction (F1) was subjected to preparative paper were obtained containing two band. Then each band was purified on column sephadex LH-20 and the eluting system was ethanol (compound $1,2)$.

\subsubsection{Identification of Compound 1}

Colorless in visible, oily liquid, $\mathrm{Rf}$ value in solvent systems (acetic acid 15\% 0.90, B.A.W. (4:1:5) 0.94). ${ }^{1} \mathrm{H}-\mathrm{NMR}$ in $\mathrm{CDCL}_{3} \delta$ (ppm) 7.72 $\left(2 \mathrm{H}, d d, J=5.6,3.2 \mathrm{H}_{\mathrm{Z}}, \mathrm{H}-2,5\right), 7.53(2 \mathrm{H}, d d, J$ $=5.6,3.2 \mathrm{~Hz} \mathrm{H}-3,4), 4.19-4.27(4 \mathrm{H}, m,-\mathrm{O}-$ $\left.\mathrm{CH}_{2}\right), 1.67-1.71\left(2 \mathrm{H}, m,-\mathrm{CH}\right.$ at $\left.4,4{ }^{\prime \prime}\right), 1.23$ - $1.39\left(16 \mathrm{H}, m,-\mathrm{CH}_{2}\right.$ at 5', 5“, 6’, 6“, 7`, 7“9', 9“) $0.89-0.95(\mathrm{~m}, 12 \mathrm{H},-$-methyl groups). IR $(\mathrm{KBr} \mathrm{cm}-1) ; 1600(\mathrm{C}=\mathrm{C}), 1727(\mathrm{C}=\mathrm{O}), 2931$ (C-H aliphatic) and 2960 (O-H aromatic). Mass spectrum: $\mathrm{M}$. wt $=390 \mathrm{~m} / \mathrm{z}$, molecular formula $\mathrm{C}_{24} \mathrm{H}_{38} \mathrm{O}_{4}[\mathrm{M}]{ }^{+} \mathrm{m} / \mathrm{z}$ (391), m/z (331), m/z (286), m/z (244), m/z 89, m/z (100 base peak).

From the previously mentioned data and by comparing with those published before [19], compound 1 was identified as di-(2-ethylhexyl) phthalate (DEHP).<smiles>CCCCC(CC)CC(CC)COC(=O)c1ccccc1C(=O)OCC</smiles>

Fig. (3): Di-(2-ethylhexyl) phthalate (DEHP) 


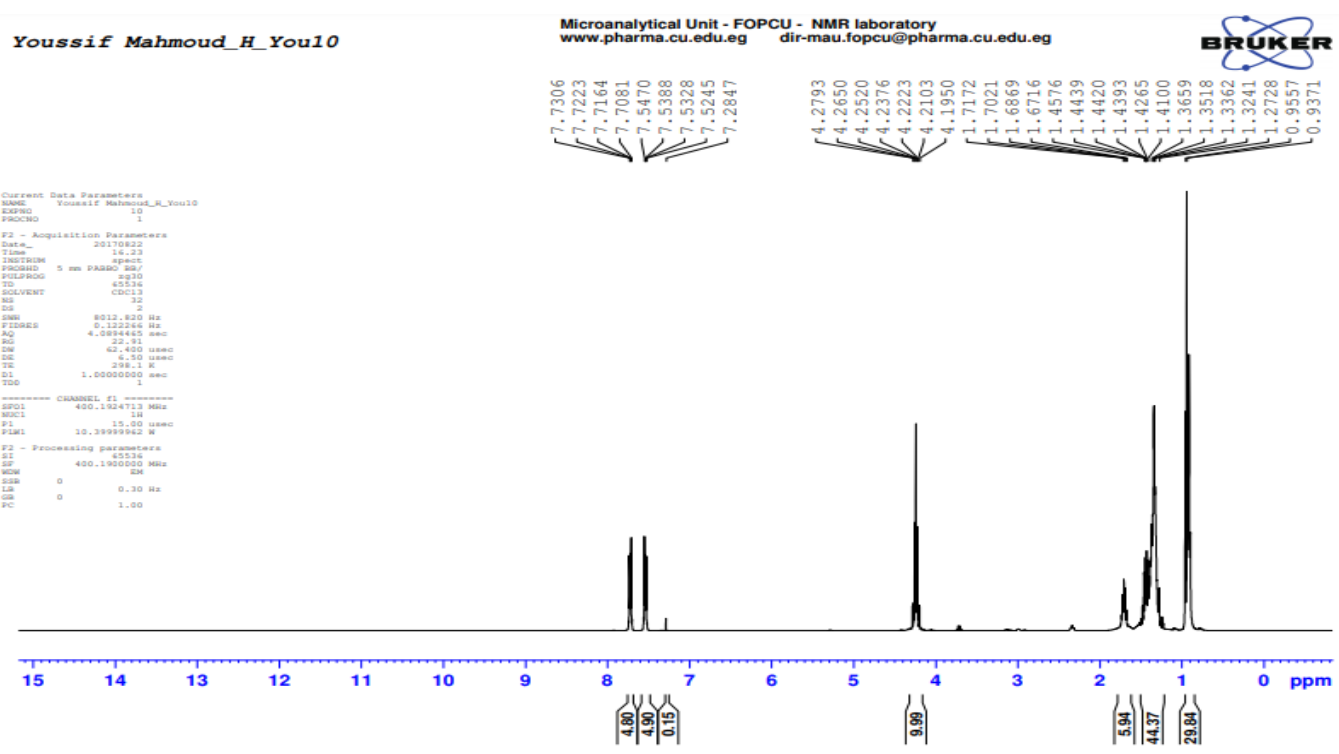

Fig. (4): ${ }^{1} \mathrm{H}$ NMR spectrum of compound 1

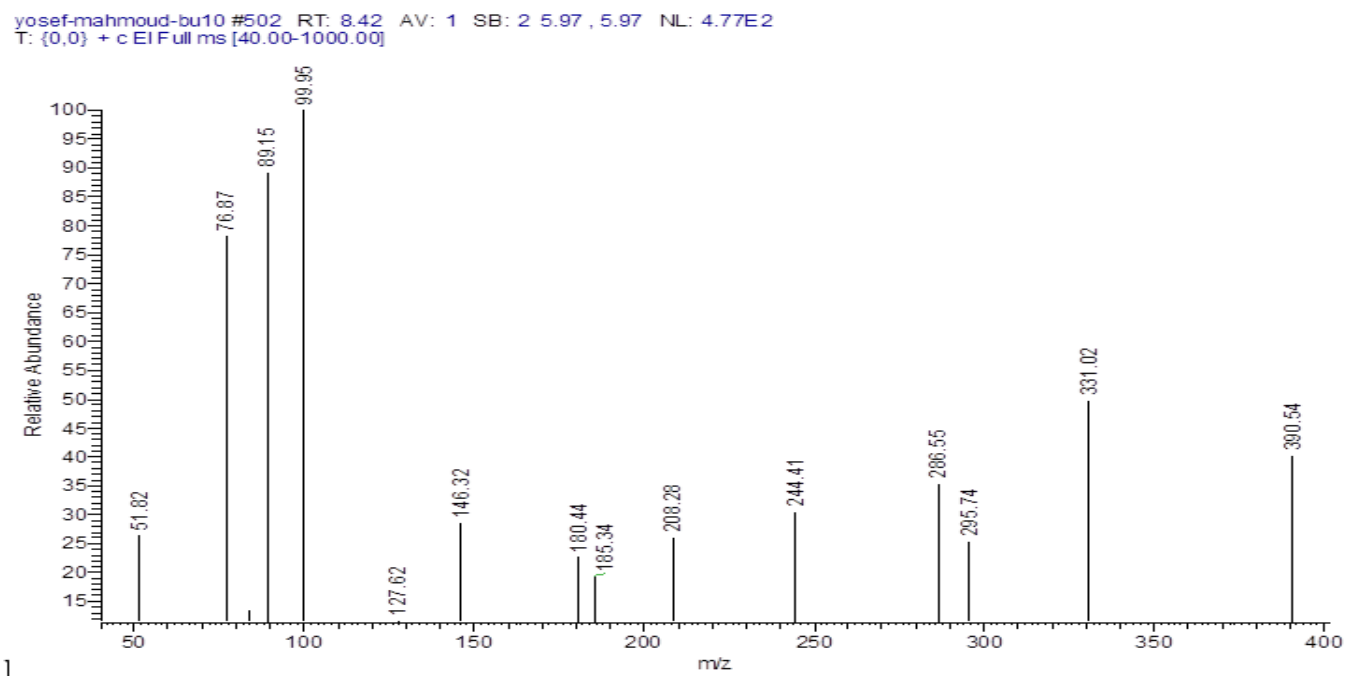

Fig. (5): Mass spectrum of compound 1

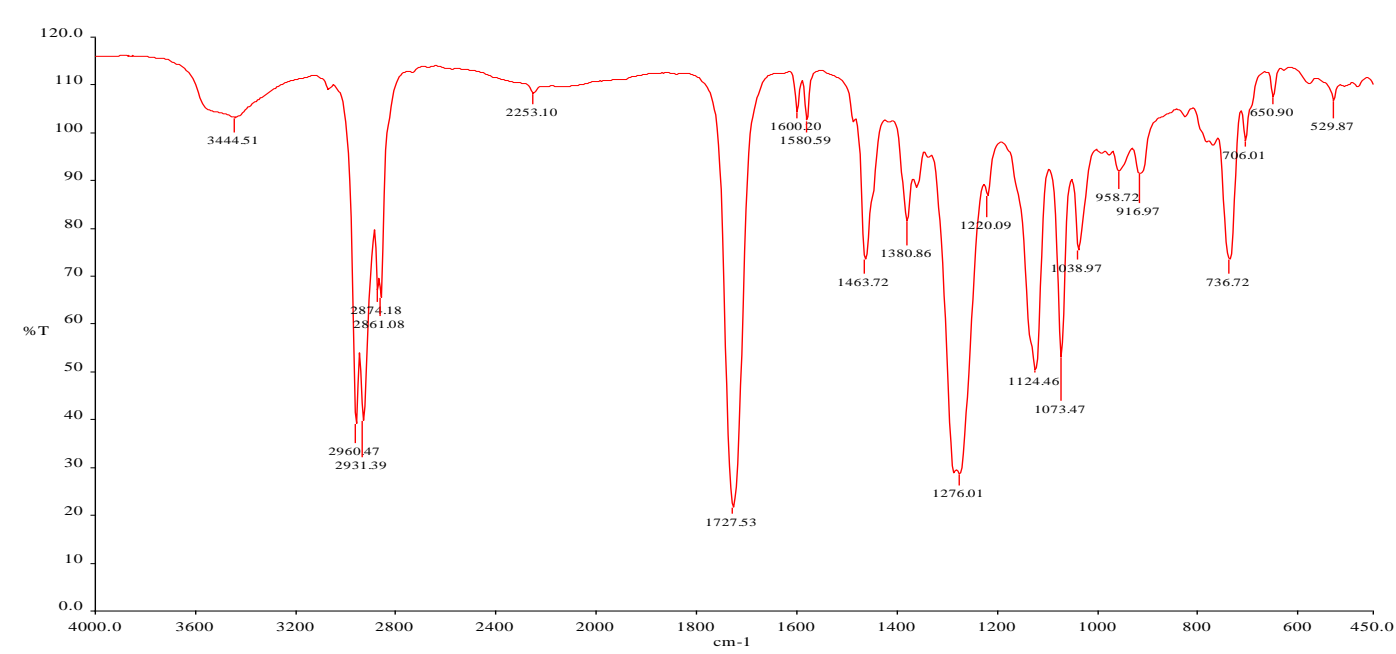

Fig. (6) IR spectroscopy of compound 1 


\subsubsection{Identification of compound 2}

Colorless, gum and insoluble in water. Rf value in solvent systems (acetic acid 15\% 0, B.A.W. (4:1:5) 0.49). ${ }^{1} \mathrm{H}-\mathrm{NMR}$ in $\mathrm{CD}_{3} \mathrm{OD}: \delta$ (ppm) $7.3(1 \mathrm{H}, d, J=2.8 \mathrm{~Hz}, \mathrm{H}-2), 6.8(1 \mathrm{H}, d d$, $J=2.8, J=8.4 \mathrm{~Hz}, \mathrm{H}-6), 6.6(1 \mathrm{H}, d, J=8.8$ $\mathrm{Hz}, \mathrm{H}-5)$. IR (KBr, cm-1): $1580(\mathrm{C}=\mathrm{C}), 1680$ $(\mathrm{C}=\mathrm{O}), \quad 2925 \quad(\mathrm{C}-\mathrm{H}), \quad 3448 \quad(\mathrm{O}-\mathrm{H})$. Mass spectroscopy: $\mathrm{M} \quad \mathrm{wt}=154 \mathrm{~m} / \mathrm{z}$, molecular formula $\mathrm{C}_{7} \mathrm{H}_{6} \mathrm{O}_{4}, \mathrm{~m} / \mathrm{z}(154), \mathrm{m} / \mathrm{z}(138), \mathrm{m} / \mathrm{z}$ (535 base peak), m/z (110), m/z (94), m/z (58) $\mathrm{m} / \mathrm{z}(53)$ base peak.

From the previously mentioned data and by comparing with those published before [20], compound 2 was identified as protocatechuic acid

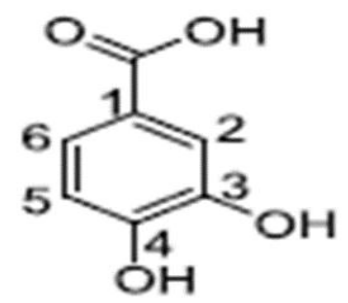

Fig. (7): Protocatechuic acid

\subsection{Antibacterial activity}

The different organic extracts of the aerial part of H.hemostimon J.Gay were screened for antibacterial activity against five bacterial species in a disc-diffusion assay. The results showed the effect of all extract except ethanol $70 \%$ extract, which had no effect against tested bacteria fig. (11). It also observed that the diethyl ether and ethyl acetate fractions were displayed broad spectrum among the remaining five fractions, whereas it showed a zone of inhibition ranged between 12 to $17 \mathrm{~mm}$ against all tested gram positive bacteria (Bacillus subtilus, Enterococcus faecalis and Staphylococcus aureu) and gram negative (Escherichia coli and Pseudomonas aeruginosa). Chloroform and ethanol 96\% fraction were less activity from the diethyl ether and ethyl acetate fractions, whereas they showed antibacterial activity against tested bacteria except E. faecalis. Less antibacterial effect on gram positive tested bacteria was observed by petroleum ether fraction, whereas there is no inhibition activity against $B$. subtilus and E. faecalis, on the other hand the same fraction showed inhibition zone against two gram negative tested bacteria ranged $16 \mathrm{~mm}$ and $13 \mathrm{~mm}$ in diameter on E. coli and $P$. aerugino sa table (6).

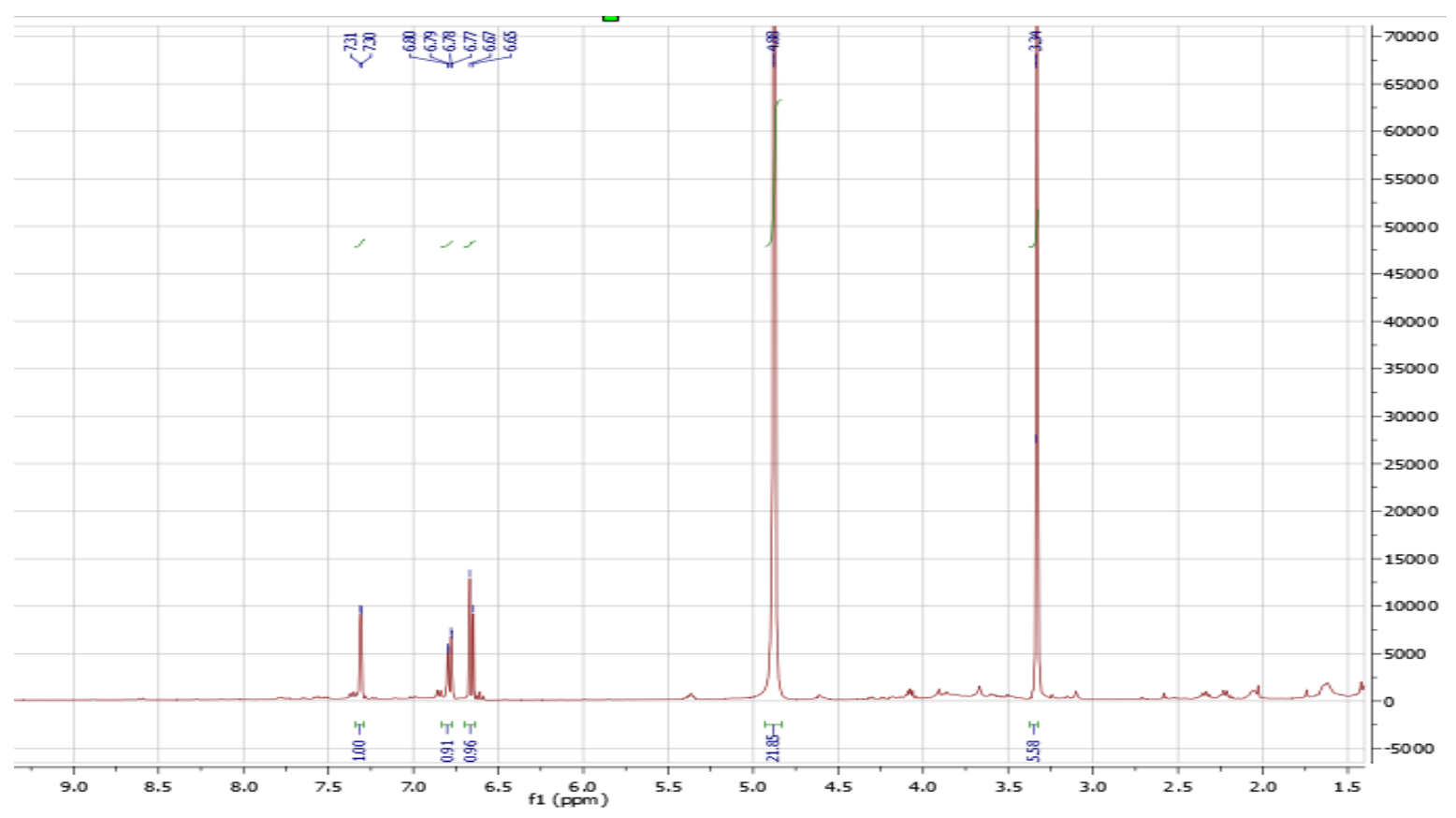

Fig. (8): 1H-NMR spectrum of compound 2 


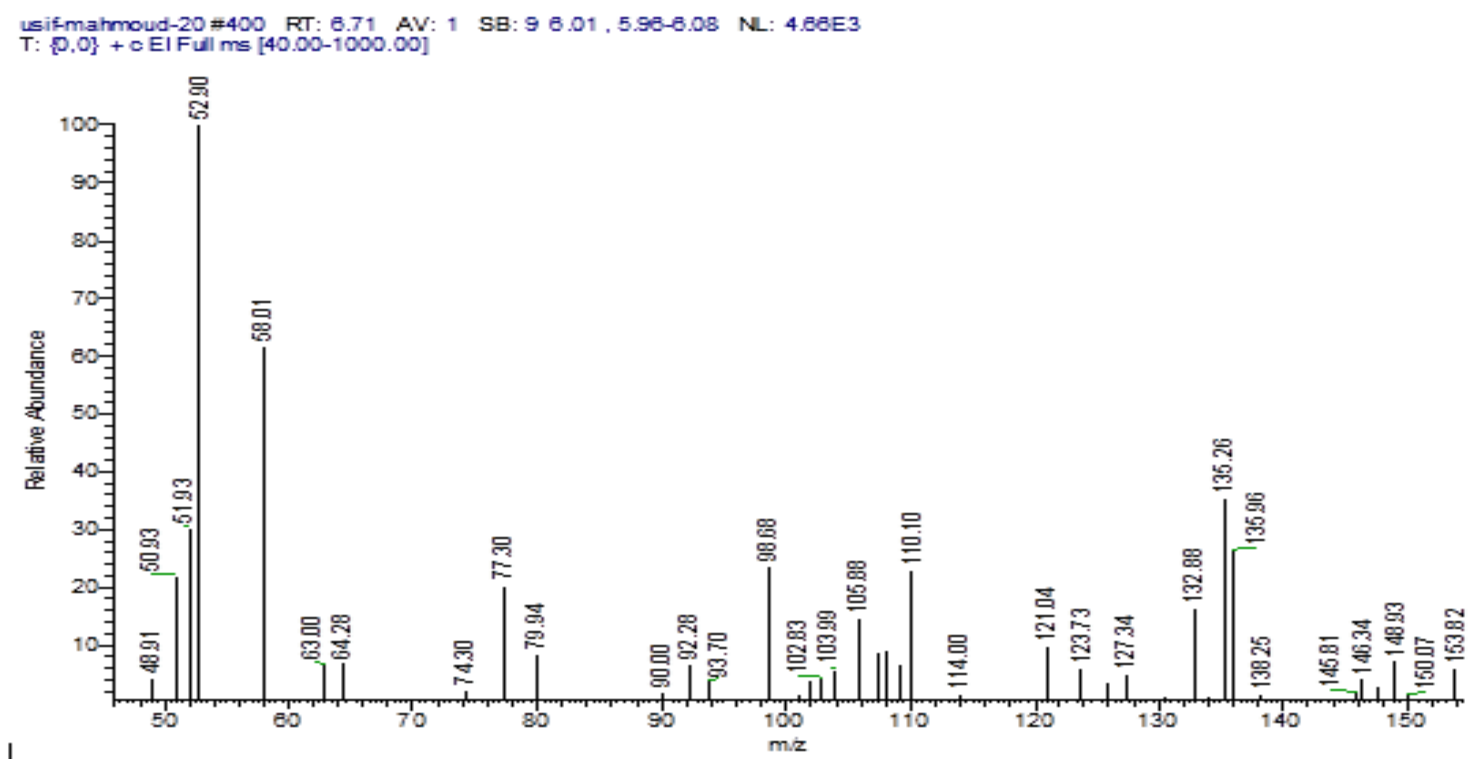

Fig. (9): Mass spectrum of compound 2

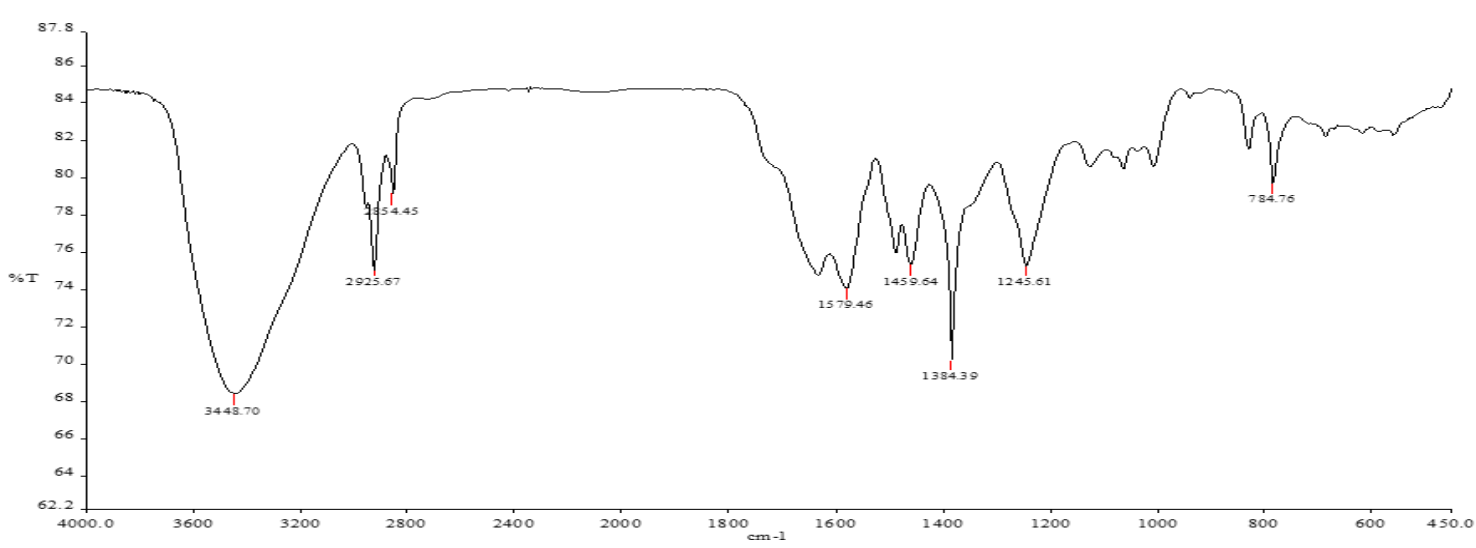

Fig. (10): IR spectroscopy of compound 2

Table (6). Antibacterial activity of successive fractions of Herniaria hemistemon

\begin{tabular}{|c|c|c|c|c|c|c|}
\hline \multirow{2}{*}{ Bacteria } & \multicolumn{7}{|c|}{ Diameter of inhibition zones (mm) } \\
\cline { 2 - 7 } & $\begin{array}{c}\text { Petroleum } \\
\text { ether }\end{array}$ & $\begin{array}{c}\text { Diethyl } \\
\text { ether }\end{array}$ & Chloroform & $\begin{array}{c}\text { Ethyl } \\
\text { acetate }\end{array}$ & $\begin{array}{c}\text { Ethanol } \\
\mathbf{9 6 \%}\end{array}$ & $\begin{array}{c}\text { Ethanol } \\
\mathbf{7 0 \%}\end{array}$ \\
\hline Bacillus subtilus & 0 & 15 & 13 & 15 & 12 & 0 \\
\hline Enterococcus faecalis & 0 & 16 & 0 & 12 & 0 & 0 \\
\hline Staphylococcus aureus & 13 & 16 & 10 & 16 & 12 & 0 \\
\hline Escherichia coli & 16 & 17 & 12 & 15 & 10 & 0 \\
\hline Pseudomonas aeruginosa & 13 & 16 & 12 & 14 & 10 & 0 \\
\hline
\end{tabular}




\subsection{Antifungal activity}

Antifungal activity results were summarized in table (7) on the same trend of the antibacterial activities, all of organic solvent extracts showed antifungal activity except the ethanol 70\%. Both of the diethyl ether and ethyl acetate fractions showed good inhibition activity on aspregillus niger and candida albican, by disc diffusion method whereas the other fractions showed antifungal activity on one tested fungi without another as shown in fig. (12).

\subsection{The minimal inhibition concentration (MIC}

The minimal inhibition concentration (MIC) values of the most effective extracts diethyl ether and ethyl acetate fractions Herniaria hemistemon were determined for $B$. subtilis, $S$. aureus, $P$. aeruginosa, E. coli, Enterococcus faecalis, $A$. niger and $C$. albicans. The results showed that the levels of MIC of diethyl ether fractions range observed from 10 to $30 \mathrm{mg} / \mathrm{ml}$ and 50 to $80 \mathrm{mg} / \mathrm{ml}$ for ethyl acetate extracts respectively as showed in Table (8).

The antimicrobial effect of diethyl ether and ethyl acetate fractions of $\mathrm{H}$. hemistemon against these organisms may be due to the ability of these solvents to extract some of bioactive compounds like phenolic, saponins and other secondary metabolites which are reported to be antimicrobial effects [21, 22]. The obtained results revealed that diethyl ether and ethyl acetate fractions showed the best antibacterial and antifungal activity, these results may be contributed to the presence of flavonoids which were isolated from the plant such as, vitexin, kaempferol, quercetin-3-O-glucoside-7-Orhamnoside, kaempferol-7-O-rhamnoglucoside, and kaempferol-4'-methyl ether [5], Ellagic acid which have biological activities including antioxidant, antimicrobial and anticancer activity [23, 24, 25]. Plant possessed coumarins which can have influence in its higher antibacterial effect [32]26, the fatty acids exhibited antibacterial and antifungal properties $[27,28]$, where Ellagic acid, Coumarin, kaempferol, quercetin, and rutin, were identfided using HPLC, Vitexin (5,7,4trihydroxyflavone-8-glucoside) has wide pharmacological effects, including anti-oxidant, anti-cancer and anti-inflammatory effects [29], Quercetin and Quercetin-3-O-rhamnoside have a significant antioxidant activity [30].

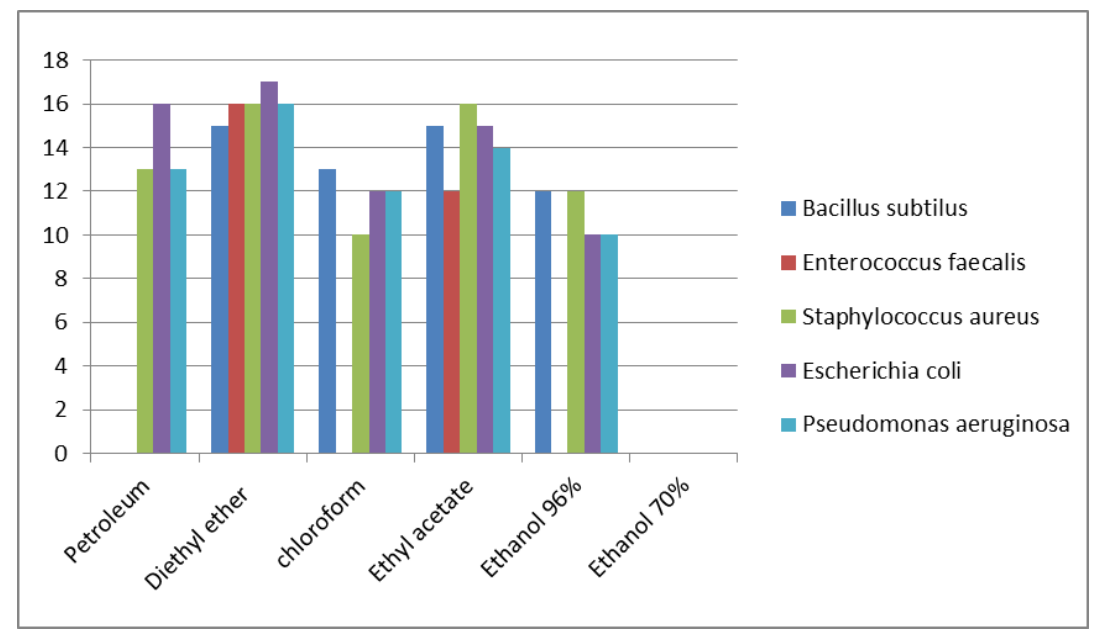

Fig. (11): Effect of successive extracts of Herniaria hemistemon on the tested strains of bacteria.

Table (7). Antifungal activity of different fractions of Herniaria hemistemona erial parts

\begin{tabular}{|c|c|c|c|c|c|c|}
\hline Fungi & $\frac{\underline{\text { Petroleum }}}{\underline{\text { ether }}}$ & $\frac{\underline{\text { Diethyl }}}{\text { ether }}$ & $\underline{\text { Chloroform }}$ & $\begin{array}{c}\text { Ethyl } \\
\text { acetate }\end{array}$ & $\frac{\underline{\text { Ethanol }}}{\underline{\mathbf{9 6 \%}}}$ & $\frac{\underline{\text { Ethanol }}}{\underline{\mathbf{7 0 \%}}}$ \\
\hline Aspergillus niger & $\underline{0}$ & $\underline{17}$ & $\underline{14}$ & $\underline{15}$ & $\underline{14}$ & $\underline{0}$ \\
\hline Candida albicans & $\underline{15}$ & $\underline{15}$ & $\underline{0}$ & $\underline{15}$ & $\underline{0}$ & $\underline{0}$ \\
\hline
\end{tabular}




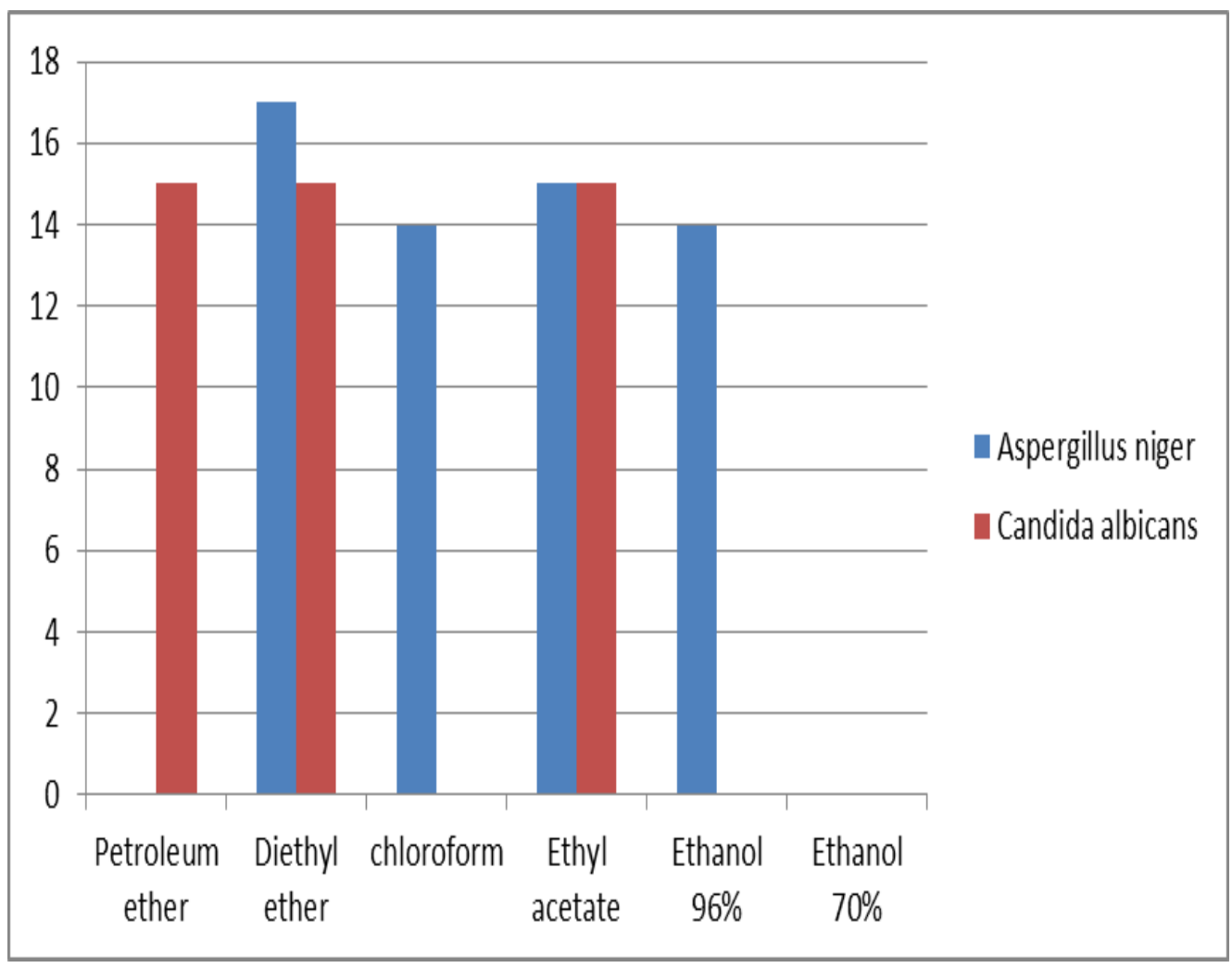

Fig. (12): Effect of successive extracts of Herniaria hemistemon on the tested strains of fungi.

Table (8). MIC ( $\mu \mathrm{g} / \mathrm{ml})$ of different plant fractions on tested Bacteria and fungi.

\begin{tabular}{|c|c|c|c|c|c|c|c|}
\hline \multirow[t]{3}{*}{ Extracts } & \multicolumn{7}{|c|}{ MIC (mg/ml) } \\
\hline & \multicolumn{3}{|c|}{ Gram +ve bacteria } & \multicolumn{2}{|c|}{ Gram -ve bacteria } & Fungi & Yeast \\
\hline & $\begin{array}{c}\text { E. } \\
\text { Faecalis }\end{array}$ & $\begin{array}{c}\text { B. } \\
\text { subtilis }\end{array}$ & $\begin{array}{c}S . \\
\text { aureus }\end{array}$ & $\begin{array}{c}P . \\
\text { aerugiosa }\end{array}$ & $\begin{array}{l}\text { E. } \\
\text { Coli }\end{array}$ & A. niger & $\begin{array}{c}C . \\
\text { albicans }\end{array}$ \\
\hline Diethyl ether & 30 & 20 & 10 & 10 & 30 & 30 & 20 \\
\hline Ethyl acetate & 50 & 80 & 70 & 70 & 50 & 80 & 80 \\
\hline
\end{tabular}

\subsection{Antioxidant activity}

Antioxidant activity using DPPH on the successive extracts of $H$. hemistemon with ascorbic acid (natural antioxidant) was carried out, ascorbic acid showed the highest radical scavenging activity attaining aplate aupattern of activity $(93.92 \%)$ of concentration (1000 $\mu \mathrm{g} / \mathrm{ml}$ ), results of antioxidant activity revealed that the scavenging activity of diethyl ether, ethyl acetate and ethanol extracts $H$. hemistemon were dose dependent as shown in Table (9) and fig.(13). The highest percent of DPPH scavenging activity was obtained by ethyl acetate extract $(92.17 \%)$ at concentration $(1000 \mu \mathrm{g} / \mathrm{ml}),(91.07 \%)$ at concentration $(500$ $\mu \mathrm{g} / \mathrm{ml})$ and $(90.91 \%)$ at concentration (250 $\mu \mathrm{g} / \mathrm{ml}$ ), and the lowest effect was obtained $(28.88 \%)$ in pet.ether extract of the plant. Percentage of DPPH scavenging effect increased dramatically with increasing concentration. From the above result, it was observed that ethyl acetate extract at concentration $(1000 \mu \mathrm{g} / \mathrm{ml})$ showed aplateau scavenging potency presuming radical scavenging activity, as result of presence of phenolic compounds as flavonoids and coumarins which regarded as a hydrogen donors having antioxidant activity [31]. 
Table (9): Scavenging activity of successive extracts of Herniaria hemistemon J.Gay against (DPPH.).

\begin{tabular}{|c|c|c|c|c|c|c|c|}
\hline \multirow{2}{*}{$\begin{array}{c}\text { Conc. } \\
(\mu \mathrm{g} / \mathrm{ml})\end{array}$} & \multicolumn{7}{|c|}{ \% Scavenging } \\
\hline & $\begin{array}{c}\text { petroleum } \\
\text { ether }\end{array}$ & diethyl ether & chloroform & $\begin{array}{l}\text { ethyl } \\
\text { acetate }\end{array}$ & $\begin{array}{c}\text { Ethanol } \\
96 \%\end{array}$ & $\begin{array}{c}70 \% \\
\text { ethanol }\end{array}$ & $\begin{array}{c}\text { ascorbic } \\
\text { acid }\end{array}$ \\
\hline 125 & 28.66 & 70.01 & 30.91 & 87.88 & 59.65 & 31.29 & 85.67 \\
\hline 250 & 36.96 & 77.40 & 32.5 & 90.91 & 66.22 & 37.01 & 88.00 \\
\hline 500 & 51.46 & 82.42 & 59.32 & 91.07 & 87.57 & 60.00 & 92.30 \\
\hline 1000 & 71.05 & 88.10 & 70.10 & 92.17 & 90.17 & 63.72 & 93.92 \\
\hline
\end{tabular}

(\%) Scavenged DPPH

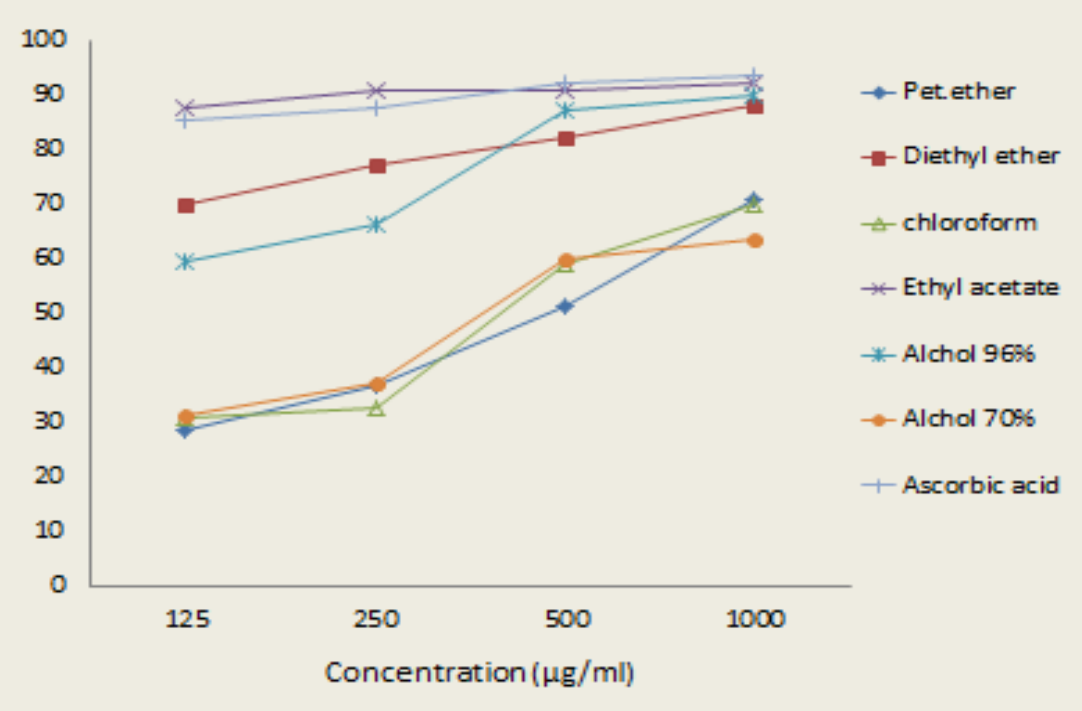

Fig. (13). Scavenging activity of successive extracts of Herniaria hemistemon J.Gay against (DPPH.).

\section{CONCLUSION:}

The current results highlighted the chemical constituents and biological effects of Herniaria hemistimon as a promising sources of future bioactive compounds..

\section{REFERENCES}

[1] Aggarwal, B. B., Kumar, A., and Bharti, A. C. (2003). Anticancer potential of curcumin: preclinical and clinical studies. Anticancer research, 23(1/A), 363-398.

[2] Newman, D. J., and Cragg, G. M. (2007). Natural products as sources of new drugs over the last 25 years. Journal of natural products, 70(3), 461-477.

[3] Ghazanfar, S. A. (1994). Handbook of Arabian medicinal plants. CRC press.
[4] Täckholm, V., 1974.Students' Flora of Egypt, 2nd. Cairo University, Egypt, 888.

[5] Radwan, H. M., Nazif, N. M., and Abou-Setta, L. M. (2006). The Lipid and flavonoidal Constituents of Herniaria hemistemon J. Gay and Their Biological activity. Egyptian journal of pharmaceutical sciences, 47, 29

[6] Bidak, L. M., Kamal, S. A., Halmy, M. W. A., and Heneidy, S. Z. (2015). Goods and services provided by native plants in desert ecosystems: Examples from the northwestern coastal desert of Egypt. Global Ecology and Conservation, 3, 433-447.

[7] Sakkir, S., Kabshawi, M., and Mehairbi, M. (2012). Medicinal plants diversity and their conservation status in the United Arab Emirates (UAE). Journal of Medicinal Plants Research, 6(7), 1304-1322. 
[8] Balbaa, S. I. (1986). Chemistry of crude drugs. Laboratory Manual Faculty of Pharmacy. Cairo University.

[9] Brieskorn, C. H., Klinger, H. and Polonius, W. (1961). Triterpenes and sterols in leaves of Salvia trioloba and Pyrusmalus. Arch Pharm. 294: 380-391.

[10] Woo, W. S., Chi, H. J., and Yunchoi, H. S. (1977). Alkaloid screening of some Saudi Arabian plants. Korean Journal of Pharmacognosy, 8(3), 109-113.

[11] Edeoga, H. O., Okwu, D. E., and Mbaebie, B. O. (2005). Phytochemical constituents of some Nigerian medicinal plants. African journal of biotechnology, 4(7), 685-688.

[12] Samatha, R., Shyamsundarachary, R., Srinivas, P., Swamy, N. R., \& Kurz, L. (2012). Total flavonoids content in some plants. American journal of applied sciences, 5(4), 177-179.

[13] Makkar, H. P. S., Singh, B., Vats, S. K., and Sood, R. P. (1993).Total phenols, tannins and condensed tannins in different parts of Rumex hastatus. Bioresource technology, 45(1), 69-71.

[14] Ali, A. A., Ross, S. A., Mesbah, M. K., and El Moghazy, S. A. (1991). Phytochemical study of Limoniumaxillare (Forssk.). Bull. Fac. Pharm. Cairo Univ, 29(3), 59-62.

[15] Honerlagen, V. H., and Tretter, H. R. (1979). Zur Routine Mabigen Quantitativen gesamtsaponinbestimmung in Radix ginseng Panax und extrakten. Dtsh, Apoth. Ztg, 14831486.

[16] Kawase, M., Sakagami, H., Hashimoto, K., Tani, S., Hauer, H., and Chatterjee, S. S. (2003). Structure-cytotoxic activity relationships of simple hydroxylatedcoumarins. Anticancer research, 23(4), 3243-3246.

[17] Matar, M. J., Ostrosky-Zeichner, L., Paetznick, V. L., Rodriguez, J. R., Chen, E., and Rex, J. H. (2003). Correlation between E-test, disk diffusion, and microdilution methods for antifungal susceptibility testing of fluconazole and voriconazole. Antimicrobial agents and chemotherapy, $\mathrm{V}$ and pages?

[18] James, C. S. (1995). Analytical chemistry of foods. Blackie academic and Professional press. Chemistry, 46, 4358-4362.

[19] El-Sayed, M. H. (2012). Di-(2-ethylhexyl) Phthalate, a major bioactive metabolite with antimicrobial and cytotoxic activity isolated from the culture filtrate of newly isolated soil Streptomyces (Streptomyces mirabilis strain NSQu-25). World Applied Sciences Journal, 20(9), 1202-1212.

[20] Chang, S. W., Kim, K. H., Lee, I. K., Choi, S. U., Ryu, S. Y., and Lee, K. R. (2009). Phytochemical constituents of Bistorta manshuriensis. Natural Product Sciences, 15(4), 234-240.

[21] Cowan, M. M. (1999). Plant products as antimicrobial agents. Clinical microbiology reviews, 12(4), 564-582.

[22] Majewska, M., Skrzycki, M., Podsiad, M., and Czeczot, H. (2011). Evaluation of antioxidant potential of flavonoids: an in vitro study. Acta poloniae pharmaceutica, 68(4), 611-615.

[23] Faried, A., Kurnia, D., Faried, L. S., Usman, N., Miyazaki, T., Kato, H., and Kuwano, H. (2007). Anticancer effects of gallic acid isolated from Indonesian herbal medicine, Phaleriamacrocarpa (Scheff.) Boerl, on human cancer cell lines. International journal of oncology, 30(3), 605-613.

[24] Yildirim, A., Mavi, A. and Kara, A. A. (2001). Determination of antioxidant and antimicrobial activities of Rumexcrispus L. extracts. J. Agric. Food Chem., 49: 4083-4089.

[25] Hagiwara, Y., Kasukabe, T., Kaneko, Y., Niitsu, N., and Okabe-Kado, J. (2010). Ellagic acid, a natural polyphenolic compound, induces apoptosis and potentiates retinoic acid-induced differentiation of human leukemia HL-60 cells. International journal of hematology, 92(1), 136143.

[26] Stavri, M., and Gibbons, S. (2005). The antimycobacterial constituents of dill (Anethum graveolens). Phytotherapy research: an international Journal devoted to pharmacological and toxicological evaluation of natural product derivatives, 19(11), 938-941.

[27] Desbois, A. P., and Smith, V. J. (2010). Antibacterial free fatty acids: activities, mechanisms of action and biotechnological potential. Applied microbiology and biotechnology, 85(6), 1629-1642.

[28] Karimi, E., Jaafar, H. Z., Ghasemzadeh, A., and Ebrahimi, M. (2015). Fatty acid composition, antioxidant and antibacterial properties of the microwave aqueous extract of three varieties of Labisia pumila Benth. Biological research, 48(1), 9.

[29] He, M., Min, J. W., Kong, W. L., He, X. H., Li, J. X., and Peng, B. W. (2016). A review on the pharmacological effects of vitexin and isovitexin. Fitoterapia, 115, 74-85.

[30] Majewska, M., Skrzycki, M., Podsiad, M., and Czeczot, H. (2011). Evaluation of antioxidant potential of flavonoids: an in vitro study. Acta poloniae pharmaceutica, 68(4), 611-615.

[31] Kawase, M., Sakagami, H., Hashimoto, K., Tani, S., Hauer, H., and Chatterjee, S. S. (2003). Structure-cytotoxic activity relationships of simple hydroxylatedcoumarins. Anticancer research, 23(4), 3243-3246. 


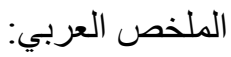

أجريـت هـذه الدر اســة لتقيـيم التـأثير ات الكيميائيـة

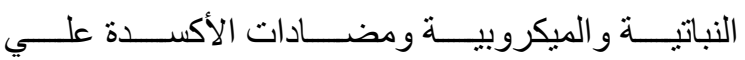

المستخلصـات الجزئية للأثثر البترولي ( •ـ ـ • ب درجـة

مئويـة) و الإيثيـل إيثـر و الكلوروفـورم و إيثيـل الأسيتات

و الإيثانول 97\% و الإيثانول • ₹\% التي تم الحصول عليها

مـن الأجز اء الهوائيـة لنبـات هرنيريـا هيستيمون ـ أظهر

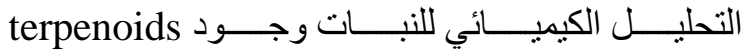

و الاستيرو لات و الفلافونويدات و القلويدات و الصـابونين.

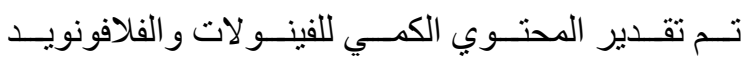

و القلويـات و الصـابونين. اظهر تحليـل HPLC للأجـز اء

الهو ائية لـ Herniaria hemostimon J.Gay وجود

ا Y مركب فلافونويـد بجانـب ال مركبـات فينوليـة. تم

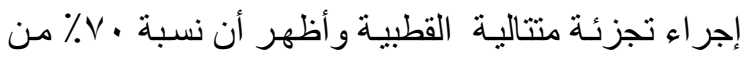

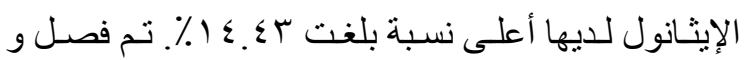

تعريف مركب ثنائي (إيثيل هكسيل) فتشالات DEHP

وحمض البروتوكاتيشويك وحُددا باستخدام FT-IR و

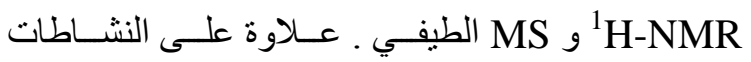

المضـادة للميكروبـات ومضــادات الأكسـدة للمسـتخلص

المتتالية القطبية من Hemistemon Herniaria ضد

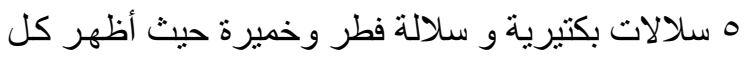

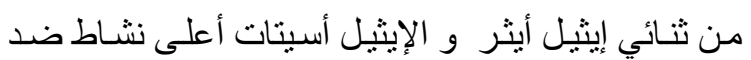
جميع السـلالات البكتيريـة و الفطريـة المختبرة بالاضـافة لإنة

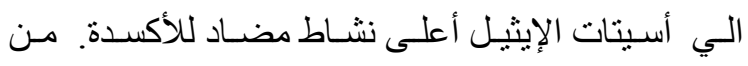

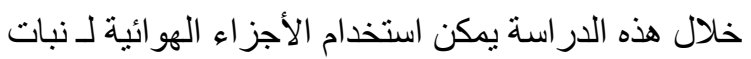
Herniaria hemistemona بسبب الأنشطة المضـادة للأكسدة و المضـادات البكتيريـة و 